\title{
Assessment of Environmental Burdens of the Current Disposal Method of Municipal Solid Waste in Kuwait vs. Waste-to-Energy Using Life Cycle Assessment (LCA)
}

\author{
Ayed A. Al-Fadhli
}

\begin{abstract}
Life cycle assessment (LCA) is gaining wider acceptance as a method that evaluates the environmental burdens associated with a product, process or activity by identifying and quantifying the energy, materials used and wastes released to the environment. It is also considered as one of the best environmental management tools that can be used to compare alternative eco-performances of recycling or disposal systems. In this study, life cycle assessment of municipal solid waste (MSW) is reviewed to protect global environment and to control waste in the state of Kuwait. As the incremental population in Kuwait results in a dramatic increase in the MSW and unfortunately, the waste management system in the region has not been properly managed, yet. The study aimed to analyze potential environmental burdens of different waste-to-energy technologies through LCA model. The results of an attributional life cycle assessment (LCA) study are presented for three scenarios reflecting the management of municipal solid waste (MSW). The first (baseline) scenario reflects the current treatment of MSW, where plastic solid waste (PSW) and organics are landfilled. Scenarios II and III encompass a low-temperature pyrolysis (LTP) and hydrocracker units, respectively.

It was found that a reduction of $75 \%$ in global warming potential (GWP), acidification potential (AP), photochemical eutrophication potentials (EP) and ozone creation (POCP) due to re-routing the PSW and Organics also, Incineration units Combined Heat and Power (IU-CHP) were found as huge reduction contributor of the studied pollutants over and above the Thermo-Chemical Treatment (TCT) unit.
\end{abstract}

Index Terms-Municipal solid waste (MSW), waste-to-energy (WTE), life cycle assessment (LCA), incineration landfill.

\section{INTRODUCTION}

Different waste treatment options are available in the current time with different level of problem solving and resource recovery facilities. All of the waste management options have some benefits, as well as some problems while applying in practical cases. There is no such a single technology that can solve the waste management problem fully. Therefore, it is important to integrate different waste management technology in a strategic way to achieve the sustainable waste management objectives.

However, it is difficult to select a particular technology for sustainable waste management decision or policy making processes without knowing the different technologies and

Manuscript received April 1, 2015; revised July 17, 2015.

Ayed A. Al-Fadhli is with Kuwait Petroleum Corporation, P.O. Box 26565, 13126, Safat, Kuwait (e-mail: ayf@kpc.com.kw). their impacts on the environment. Due to lack of information on impacts from certain technology, sometimes wrong decision has been made and which might arise adverse and critical situation in future. Therefore, it's important to know different technology through comparative study for different options and that might be a guiding tool for decision making processes. Different system analysis tool [1] can be the key tool to analyze different technology and their socio-economic and environmental performance. LCA is one of the important tools that have been considered in the research work for analyzing two different WTE technologies like a low-temperature pyrolysis (LTP) and hydrocracker units.

The paper aimed to analyze environmental performance of the waste-to-energy technology based on the energy recovery facilities through LCA model. Therefore, LCA model was developed based on the emissions and the resource recovery from the different waste treatment technologies. It was assumed in this study establishment of an incineration unit (IU) with a combined heat and power (CHP) which will process the municipal solid waste (MSW) fraction currently being landfilled as base case.

WTE Technologies: Municipal solid waste (MSW) to energy conversion has now been considering one of the optimal methods to solve the waste management problem in a sustainable way. Different advanced mechanical biological and thermo-chemical waste-to-energy technologies have now been applying for managing MSW. The primary goal of these technologies is to manage MSW and also recover energy from it. In our research work, we have considered two different WTE technologies like a low-temperature pyrolysis (LTP) and hydrocracker units. Brief descriptions of these technologies are given bellow:

Low Temperature Pyrolysis Technology

The pyrolysis technology incorporated in this work is the BP® low temperature pyrolysis (LTP) or polymer cracking technology has been described previously by Tukker [2] and Perugini [3]. This pyrolysis technology was commissioned by $\mathrm{BP} \circledast$ in a pilot scale and is also known as BP cracking technology. The process accepts dry plastics as indicated by the feed criteria described in Table IV. It was assumed that the unit receives a PSW feed of 50,000 tpa from the plastics produced in Kuwait, which mainly consists of polyolefins (polyethylene and polypropylene) (83\%) [2].

Veba-Combi Cracking Hydrogenation

By definition, hydrogenation is the process of molecular cracking into highly reactive free radicals which are saturated with hydrogen as they form. The process integrated here and previously described by Tukker et al. [2] is known as the VCC process. The main criterion of polyolefin feed is concerned 
with the PVC content $(\leq 10 \%)$ and in this study the VCC unit has a polyvinyl chloride (PVC) content of $10 \%$. The feed in such processes is typically sent to a depolymerising unit to produce a light top product (consisting of $71 \mathrm{wt} \% \mathrm{C} 5+$, with a boiling range of $400^{\circ} \mathrm{C}$ and non-condensable (C3-C4) gases) and a heavy bottom product. The main product of this process is the syn-crude produced, which can replace crude oil in a 1:1 ratio.

Most of the study that cited in the paper, have been analyzed the environmental performance of the WTE option individually and not considering only based on the energy generation efficiency and environmental performance. However, this study is done only based on the electricity generation rate from the different WTE system and environmental performance while managing municipal solid waste. Even though, the study has limitation while considering only emissions data for comparative resource recovery option but the study is important from the analytical point of view to identify the environmentally favorable waste treatment option while considering resource recovery option in waste management system.

Goal and Scope: The goal of the study is to analyze different waste-to-energy facilities based on energy generation and environmental impact potentials. The study is carried out by considering the energy recovery and emissions potential from the each WTE technology. LCA model consider from the cradle to death impact analysis that means from the waste generation, transportation storage, treatment and disposal of final residue. However, in this study is considered only electricity generation potentials and environmental impact associated with the emissions from the system. Therefore, a small part of the waste management system is analyzed in this study.

The burdens included in this study are global warming potential (GWP, kg CO2-eq), acidification potential (AP, kg SO2-eq), photochemical ozone creation potential (POCP, kg $\mathrm{C} 2 \mathrm{H} 4-\mathrm{eq})$ and eutrophication potential (EP, $\mathrm{kg}$ ). GWP is derived by the summation of the single activities or processes burdens with respect to their GWP factor to assess the carbon footprint. Off-setting factors were extracted from Gabi 5 software database [13]. The burdens were calculated according to the following formula:

$$
B_{j}=\sum_{i=1}^{N} b c_{j, i} x_{i}
$$

where $b c j, i$ is burden $\mathrm{j}$ from subsystem or activity $i$ and $x i$ is a mass or energy flow associated with that activity and the total life cycle inventory in this study was reported as the sum of the Direct burdens and Indirect burdens subtracted from Avoided burdens [4].

\section{WASTE MANAGEMENT OVERVIEW OF KUWAIT}

The state of Kuwait is a small country hosting just over 4,091,933 inhabitants with an oil dependent economy. Municipal solid waste (MSW) in Kuwait is not treated by any official governmental scheme. In general, the Kuwait Municipality is responsible for collecting, transporting and disposing of the solid waste generated in Kuwait. The municipality started providing its services to the public fifty years ago. Initially, waste were collected manually and transported by mule wagons, to be dumped outside the city limits.

The organic fraction of waste accounts for $44.4 \%$ of MSW in Kuwait and estimated to be generated at a rate of 1,056,120 tonnes per year. In addition, the plastic solid waste (PSW) fraction is estimated to be $11.2 \%$ of MSW [5]. Recycling and waste management in Kuwait are poor with waste accumulation levels unaccounted for by the state. Minimalistic attempts of recycling occur for plastic solid waste (PSW), metal and steel in private holding companies processing lines. No governmental scheme exists in Kuwait for municipal waste recycling and segregation of waste occurs manually at landfill sites.

The average citizen in Kuwait produces $1.4 \mathrm{Kg} / \mathrm{day}$ of Municipal Solid Waste (MSW), where a western countries citizen generates within same average, and selected countries in Fig. 1.

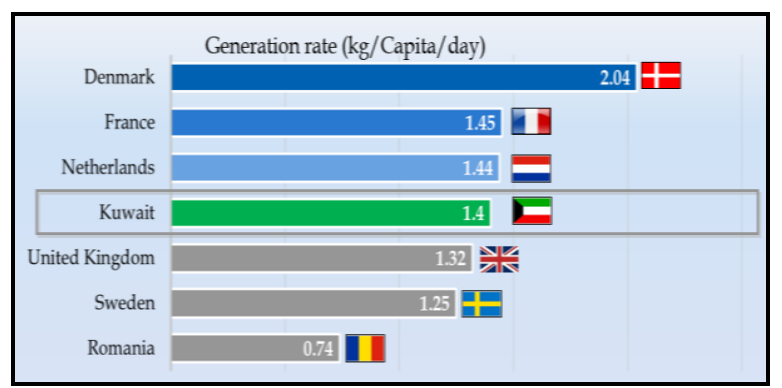

Fig. 1. Citizen waste generation in Kuwait \& selected countries in EU.

Municipal solid waste (MSW) is by far the most heterogeneous of all refuse, and is a direct result of activities in urban environments (cities, villages, municipalities). MSW consists of an organic fraction (wet waste: kitchen waste, food waste, straw, garden trimmings, sawdust, etc.) and a non-organic fraction (dry waste: glass, plastics, metals, ash, atone and bricks, etc.). The properties of waste differ immensely depending on many factors, such as the area of collection (rural, urban, industrial or commercial), seasonal variations and recycling levels [6]. Value from PSW should be recovered through either recycling or energy and fuel recovery. Residual waste from different recycling processes (i.e. refuse-derived fuel, RDF) should be treated separately, either by thermo-chemical means or by incineration (IU-CHP), and energy that is then recovered as heat or electricity, can be used for power generation.

PSW recycling processes can be allocated into four major categories [7] re-extrusion (primary), mechanical (secondary), chemical (tertiary) and energy recovery (quaternary). Each method provides a unique set of advantages that makes it particularly beneficial for logistical requirements, applications or requirements. Primary treatment involves the introduction of plastic scrap into the heating system of a plant, and may be referred to as in-house recycling. Mechanical recycling (i.e. secondary or material recycling) involves physical treatment. Chemical recycling (encompassing feedstock recycling) produces feedstock chemicals for the chemical industry, and energy recovery involves complete or partial oxidation of the material, producing heat, power 
and/or gaseous fuels, oils and chars in addition to by-products that must be disposed of, e.g. ash.

\section{SCOPE DEFINITION}

This work is based on the conditions of the state of Kuwait and considers average data for all processes based on unit operations. Hence, the results of this work may differ when considering marginal data for energy in other countries.

\section{A. Functional Unit $(F U)$}

The functional unit (FU) considered in this study is the total amount of plastic solid waste (PSW) and organic waste produced by the population of Kuwait, which is around $1.3 \mathrm{x}$ $10^{6}$ tpa. The population of Kuwait was based on the total population of the six governorates in the country as counted by the Public Authority for Civil Information (PACI) in March 2015 [8]. PSW produced in Kuwait is estimated as $0.18 \mathrm{~kg} /$ person.day [9], which was the basis of the calculations (Table I).

\begin{tabular}{lccc}
\multicolumn{4}{c}{ TABLE I: KUWAIT POPULATION AND WASTE GENERATION } \\
\hline \hline Governorate & $\begin{array}{c}\text { Residents } \\
\text { (Capita) }\end{array}$ & $\begin{array}{c}\text { PSW } \\
\text { Generation } \\
\text { (tpa) }\end{array}$ & $\begin{array}{c}\text { Organics } \\
\text { Generated } \\
\text { (tpa) }\end{array}$ \\
\hline Al Asemah & 538,930 & 36,903 & 139,095 \\
Hawalli & 899,278 & 61,577 & 232,099 \\
Al Farwanyiah & $1,095,453$ & 75,010 & 282,730 \\
Al Ahmadi & 827,634 & 56,671 & 213,608 \\
Mub. Al Kabeer & 233,305 & 15,975 & 60,215 \\
Al Jahra & 497,392 & 34,058 & 128,374 \\
Total & $\mathbf{4 , 0 9 1 , 9 9 3}$ & $\mathbf{2 8 0 , 1 9 5}$ & $\mathbf{1 , 0 5 6 , 1 2 0}$ \\
\hline \hline
\end{tabular}

\section{B. System Boundaries, Limitations and Development of Studied Scenarios}

Three scenarios are developed and modelled on Kuwait's existing energy and waste management. The first scenario depicts the current treatment of PSW and organics in the state and is shown in Fig. 2. PSW generated is landfilled along with organics with no prior treatment or recycling. The burdens associated with such case are considered in the scenario studied. In addition, the burdens associated for the production of liquefied petroleum gas (LPG), naphtha and domestic fuel gas are considered in all scenarios. This is done to account for the off-set (displaced) products of the thermo-chemicals treatment (TCT) units, in order to give a more accurate picture of the effect of integrating such units with the existing scheme (scenario 1).

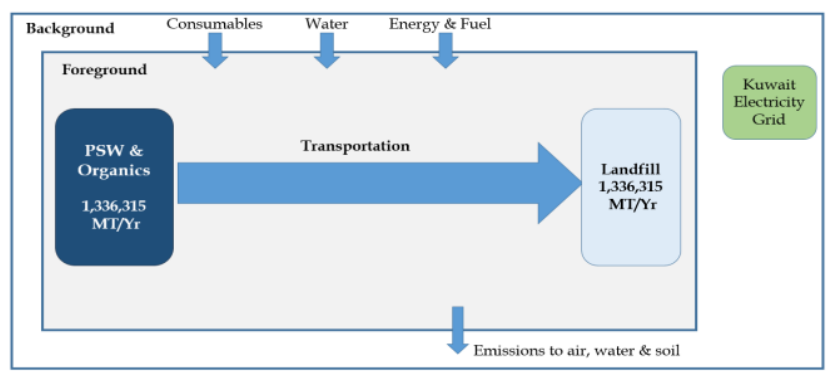

Fig. 2. Scenario I.

Scenario 2 considers a low temperature pyrolysis (LTP) reactor and an incineration unit (IU-CHP) with combined heat and power (CHP). The LTP is dedicated for PSW treatment and the IU is used to produce energy from the organics produced in Kuwait (Fig. 3). Similarly, in scenario 3 a hydrocracking unit is used to treat the PSW fraction. This is done to assess the optimal option for PSW treatment and the environmental on the proposed scenarios (Fig. 4).

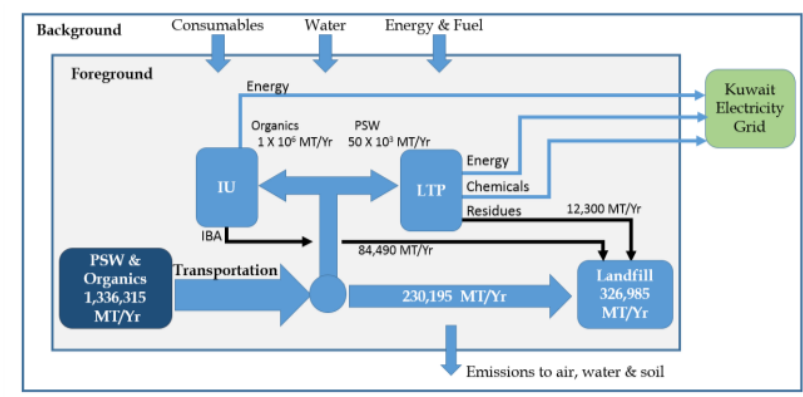

Fig. 3. Scenario II.

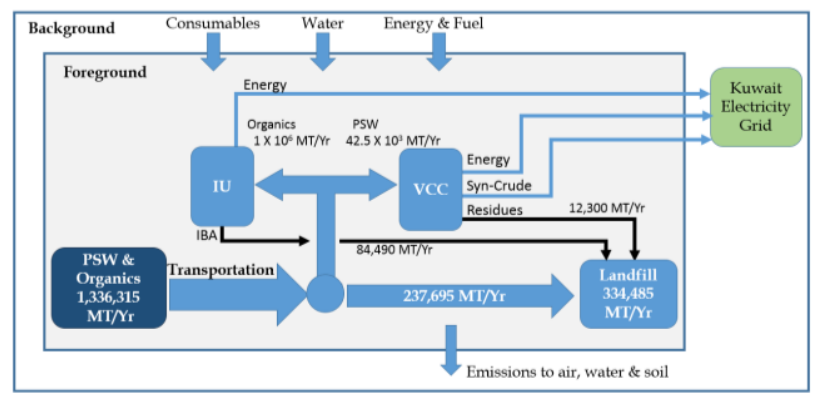

Fig. 4. Scenario III.

TABLE II: SUMMARY OF INPUTS AND OUTPUTS CONSIDERED IN THIS STUDY FOR THE LTP PROCESS AND THEIR OFF-SETTING FACTORS [3]

\begin{tabular}{|l|l|}
\hline Input Materials & Amount Required \\
\hline Sand & $0.0085 \mathrm{~kg} / \mathrm{kg}$ Feed \\
\hline $\mathrm{CaO}$ & $0.046 \mathrm{~kg} / \mathrm{kg}$ Feed \\
\hline Water & $0.002 \mathrm{~m} 3 / \mathrm{kg}$ Feed \\
\hline Naphtha & $0.131 \mathrm{MJ} /$ tonne Feed \\
\hline Electric energy & $0.212 \mathrm{MJ} /$ tonne Feed \\
\hline Output Products & Amount Obtained \\
\hline Gases (C3-C4) & $0.147 \mathrm{~kg} / \mathrm{kg}$ Feed \\
\hline Liquid (Naphtha) & $0.265 \mathrm{MJ} / \mathrm{kg}$ Feed \\
\hline Wax (AR) & $0.448 \mathrm{~kg} / \mathrm{kg}$ Feed \\
\hline $\mathrm{CaO}$ & $0.04 \mathrm{~kg} / \mathrm{kg}$ Feed \\
\hline $\mathrm{CaCl} 2$ & $0.077 \mathrm{~kg} / \mathrm{kg}$ Feed \\
\hline $\mathrm{P}-$ Steam (Heating) & $1.48 \mathrm{MJ} / \mathrm{kg}$ Feed \\
\hline $\mathrm{CO} 2$ & $0.345 \mathrm{~kg} / \mathrm{kg}$ Feed \\
\hline NOx & $0.003 \mathrm{~kg} / \mathrm{kg}$ Feed \\
\hline Sand \& Coke & $0.076 \mathrm{~kg} / \mathrm{kg}$ Feed \\
\hline Waxy filter & $0.046 \mathrm{~kg} / \mathrm{kg}$ Feed \\
\hline
\end{tabular}

\section{Processes and Unit Operations Considered}

\section{1) Transportation}

Transportation contributes to the total environmental burden in terms of airborne pollutants and these include carbon monoxide $(\mathrm{CO})$, nitrogen oxides $\left(\mathrm{NO}_{\mathrm{x}}\right)$, Hydrocarbons ( $\mathrm{HC})$. Carbon dioxide $\left(\mathrm{CO}_{2}\right)$ is also considered as a part of the transportation load activity. The contribution of $\mathrm{CO}_{2}$ is the result of the diesel consumed by the trucks that transport the waste collected from different households in each governorate to the landfill. The transportation burden is 
considered a direct emission that is added to the final impact assessment. The transportation distances vary between the different units operations considered in this work. An average distance between the center of each governorate to the landfill is taken as 25 miles.

\section{2) Thermo-chemical treatment (TCT)}

In this study two TCT industrial technologies (the BP ${ }^{\circledR}$ low-temperature pyrolysis (LTP) and VCC ${ }^{\circledR}$ hydrogenation processes) were incorporated in the overall system developed.

Both LTP \& VCC processes were assumed to have a capacity of $50 \mathrm{ktpa}$ and the other basic data considered in this study for LTP in the Table II and Table III and for VCC in Table IV and Table $\mathrm{V}$ to illustrated the main input materials and chemicals produced and their off-setting values considered respectively [10].

TABLE III: SUMMARY OF OFF-SETTING FACTORS USED FOR THE LTP

\begin{tabular}{|c|c|c|}
\hline \multicolumn{3}{|c|}{ PROCESS [11]-[14] } \\
\hline Output Products & GWP & $\mathrm{AP}$ \\
\hline Gases (C3-C4) & $1.3 \mathrm{~kg} \mathrm{CO}_{2-\mathrm{eq}} / \mathrm{kg}$ & $0.19 \mathrm{~kg} \mathrm{SO}_{2-\mathrm{eq}} / \mathrm{kg}$ \\
\hline Liquid (Naphtha) & $1.3 \mathrm{~kg} \mathrm{CO}_{2-\mathrm{eq}} / \mathrm{kg}$ & $0.19 \mathrm{~kg} \mathrm{SO}_{2-\mathrm{eq}} / \mathrm{kg}$ \\
\hline Wax (AR) & $1.3 \mathrm{~kg} \mathrm{CO}_{2-\mathrm{eq}} / \mathrm{kg}$ & $0.19 \mathrm{~kg} \mathrm{SO}_{2-\mathrm{eq}} / \mathrm{kg}$ \\
\hline P- Steam (Heating) & $0.533 \mathrm{~kg} \mathrm{CO}{ }_{2-\mathrm{eq}} / \mathrm{kWh}$ & $1.07 \times 10^{-5} \mathrm{~kg} \mathrm{SO}_{2-\mathrm{eq}} /$ \\
\hline NOx & $8 \mathrm{~kg} \mathrm{CO}_{2 \text {-eq }} / \mathrm{kg} \mathrm{NOx}$ & MJ \\
\hline & & $0.7 \mathrm{SO}_{2-\mathrm{eq}} / \mathrm{kg}$ \\
\hline Output Products & POCP & EP \\
\hline Gases (C3-C4) & $1.48 \mathrm{~kg} \mathrm{C}_{2} \mathrm{H}_{4-\mathrm{eq}} / \mathrm{kg}$ & $38.8 \mathrm{~kg} \mathrm{PO}_{4}{ }^{3-}-\mathrm{eq} / \mathrm{kg}$ \\
\hline Liquid (Naphtha) & $1.48 \mathrm{~kg} \mathrm{C}_{2} \mathrm{H}_{4-\mathrm{eq}} / \mathrm{kg}$ & $38.8 \mathrm{~kg} \mathrm{PO}_{4}{ }^{3-}{ }^{-\mathrm{eq}} / \mathrm{kg}$ \\
\hline Wax (AR) & $1.48 \mathrm{~kg} \mathrm{C}_{2} \mathrm{H}_{4-\mathrm{eq}} / \mathrm{kg}$ & $38.8 \mathrm{~kg} \mathrm{PO}_{4}{ }^{3-}-\mathrm{eq} / \mathrm{kg}$ \\
\hline P- Steam (Heating) & $\begin{array}{l}1.88 \times 10^{-6} \mathrm{~kg} \\
\mathrm{C}_{2} \mathrm{H}_{4-\mathrm{eg}} / \mathrm{MJ}\end{array}$ & $\begin{array}{c}8.4 \times 10^{-7} \mathrm{~kg} \mathrm{PO}_{4}{ }^{3-}{ }_{\mathrm{MJ}}^{-\mathrm{eq}} /\end{array}$ \\
\hline
\end{tabular}

TABLE IV: SUMMARY OF INPUTS AND OUTPUTS CONSIDERED IN THIS STUDY FOR THE VCC PROCESS AND THEIR OFF-SETTING FACTORS [3]

\begin{tabular}{lc}
\hline \hline Input Materials & Amount Required \\
\hline Steam & $0.112 \mathrm{MJ} / \mathrm{kg}$ Feed \\
Electric energy & $0.96 \mathrm{MJ} / \mathrm{kg}$ Feed \\
Natural gas & $4.62 \mathrm{MJ} / \mathrm{kg}$ Feed \\
$\mathrm{CaO}$ & $0.001 \mathrm{~kg} / \mathrm{kg}$ Feed \\
$\mathrm{Hydrogen}$ & $0.011 \mathrm{~kg} / \mathrm{kg}$ Feed \\
\hline Output Products & Amount Obtained \\
\hline Syncrude $($ Crude Oil) & $0.822 \mathrm{~kg} / \mathrm{kg}$ Feed \\
E-gas (Natural Gas) & $0.09 \mathrm{~kg} / \mathrm{kg}$ Feed \\
$\mathrm{HCl}$ & $0.005 \mathrm{~kg} / \mathrm{kg}$ Feed \\
$\mathrm{CaCl}$ & \\
$\mathrm{NH}_{3}$ & $0.0041 \mathrm{~kg} / \mathrm{kg}$ Feed \\
$\mathrm{Hydrocarbons}_{\mathrm{Solid} \text { waste }}$ & $0.006 \mathrm{gm} / \mathrm{kg}$ Feed \\
$\mathrm{CO}_{2}$ & $2.23 \mathrm{gm} / \mathrm{kg}$ Feed \\
\hline
\end{tabular}

TABLE V: SUMMARY OF OFF-SETTING FACTORS USED FOR THE VCC PROCESS [11]-[15]

\begin{tabular}{|c|c|c|}
\hline Output Products & GWP & $\mathrm{AP}$ \\
\hline $\begin{array}{l}\text { Syncrude (Crude Oil) } \\
\text { E-gas (Natural Gas) } \\
\mathrm{HCl}\end{array}$ & $\begin{array}{c}1.88 \times 10^{-4} \mathrm{C}_{2} \mathrm{H}_{4-\mathrm{eq}} / \mathrm{MJ} \\
1.12 \times 10^{-4} \mathrm{~kg} \mathrm{C}_{2} \mathrm{H}_{4-\mathrm{eq}} / \\
\mathrm{kWh} \\
1.48 \mathrm{~kg} \mathrm{C}_{2} \mathrm{H}_{4-\mathrm{eq}} / \mathrm{kg}\end{array}$ & $\begin{array}{c}8.4 \times 10^{-7} \mathrm{PO}_{4}{ }^{3-}{ }_{-\mathrm{eq}} / \mathrm{MJ} \\
1.76 \times 10^{-4} \mathrm{~kg} \mathrm{PO}_{4}{ }^{3-}{ }^{-\mathrm{eq}} / \\
\mathrm{kWh}^{3-} \\
38.8 \mathrm{~kg} \mathrm{PO}_{4}{ }^{3-}{ }_{-\mathrm{eq}} / \mathrm{kg}\end{array}$ \\
\hline Output Products & POCP & EP \\
\hline $\begin{array}{l}\text { Syncrude (Crude Oil) } \\
\text { E-gas (Natural Gas) } \\
\mathrm{HCl}\end{array}$ & $\begin{array}{l}1.48 \mathrm{~kg} \mathrm{C}_{2} \mathrm{H}_{4-\mathrm{eq}} / \mathrm{kg} \\
1.48 \mathrm{~kg} \mathrm{C}_{2} \mathrm{H}_{4-\mathrm{eq}} / \mathrm{kg} \\
1.48 \mathrm{~kg} \mathrm{C}_{2} \mathrm{H}_{4-\mathrm{eq}} / \mathrm{kg}\end{array}$ & $\begin{array}{l}38.8 \mathrm{~kg} \mathrm{PO}_{4}{ }^{3-}{ }_{-\mathrm{eq}} / \mathrm{kg} \\
38.8 \mathrm{~kg} \mathrm{PO}_{4}{ }^{3-}{ }^{-\mathrm{eq}} / \mathrm{kg} \\
38.8 \mathrm{~kg} \mathrm{PO}_{4}{ }^{3-}{ }_{-\mathrm{eq}} / \mathrm{kg}\end{array}$ \\
\hline
\end{tabular}

\section{3) Incineration unit (IU-CHP)}

Energy recovered from organic waste incineration was considered in this study. The plant operates an incineration unit (IU-CHP) based on the mass-burn process. The maximum capacity of the plant is assumed to be 1,060 ktpa of waste and the feed to the IU consists of organic waste produced from the six governorates of Kuwait (Table I). The electricity is generated using a $35 \mathrm{MW}$ steam turbine generator, operating at a temperature of $395^{\circ} \mathrm{C}$ and a pressure of 46 bar. The combined heat and power (CHP) plant was assumed to produce both electricity for the national grid and heat from the boiler system.

\section{4) Landfill}

The State of Kuwait have three main landfills which located at different site and size. The Fig. 5 shows the locations and contribution. The biggest contribution is for the $7^{\text {th }}$ ring road landfill by $62 \%$.

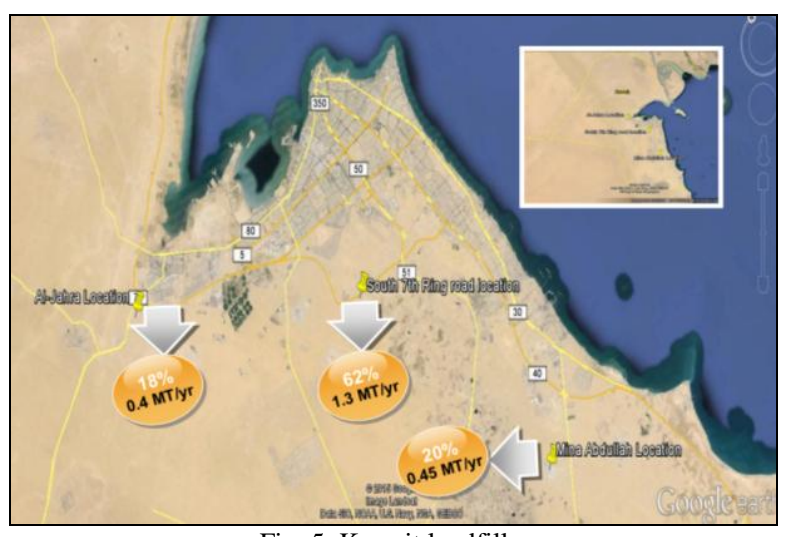

Fig. 5. Kuwait landfills.

The transportation to the landfilling site was also accounted for in this study following the same approach described previously. The fractions landfilled were assumed to be:

- $40 \%$ of the IBA produced by the IU (70 ktpa) in scenario 2 and 3.

- Waxy filter produced by the LTP process $(2.3 \mathrm{ktpa})$ in scenario 2.

- Solids produced by the LTP process (10 ktpa) in scenario 2.

- Solid waste fraction (2.5 ktpa) produced by the VCC hydrogenation (hydrocracking) process in scenario 3.

\section{RESUlts AND DiscuSSION}

In the Life Cycle approach Life Cycle Assessment (LCA) is a systematic way to evaluate the environmental impact of systems, products, materials or activities by following a "cradle-tograve" (a complete product chain) approach. This approach implies the identification and quantification of emissions and material and energy consumptions which affect the environment at all stages of the entire product life cycle. Its aim to supply decision-makers with information on the environmental impacts of activities and the possibilities for improvements.

GWP is used for each scenario to analyze the carbon savings. It was found that all scenarios studied result in a positive total GWP. However a reduction within the range 1 Million $\mathrm{Kg}$ year is anticipated compare the base case to scenario 2 and 3 which represent about $76 \%$ consideration the Transportation and Landfilling only where the biggest contribution was due to transportation. Over and above, incarnation units have a tremendous reduction of GWP by 5 
times of current $\mathrm{CO}_{2}$ emissions in compare to scenario 2 and 3 in the base case.

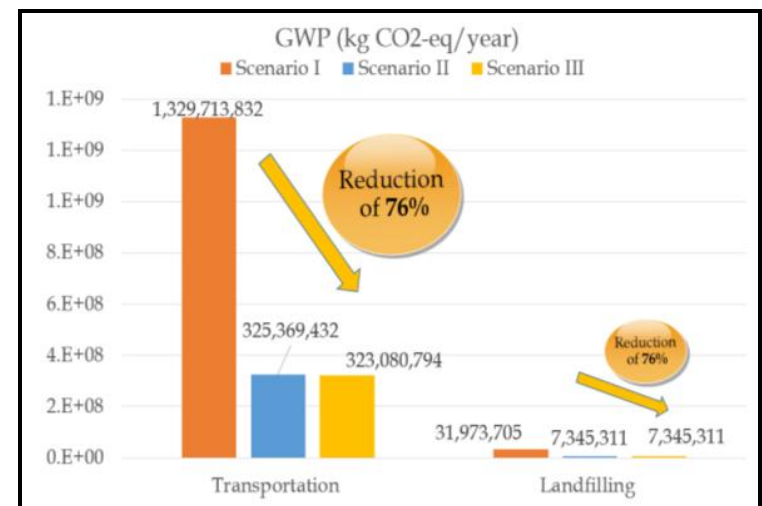

Fig. 6. Scenarios comparisons in term of GWP for Transportations and landfilling.

Similarity, for AP, EP \& POCP the reduction was in range of $75 \%$ considering the transportation and landfilling due to amount of Plastic Solid and organics extracted from Municipal Solid Waste (MSW) with different values as per the following table:

TABLE IV: SCENARIOS COMPARISONS IN TERM OF AP, EP \& POCP FOR TRANSPORTATIONS AND LANDFILLING

\begin{tabular}{cccc}
\hline \hline Factor & Scenario I & Scenario II & Scenario III \\
\hline AP SO2-eq/ kg & $1,440,490$ & 350,917 & 348,617 \\
EP PO $_{4}{ }^{3-}{ }^{-e q} / \mathrm{kg}$ & $1,351,653$ & 330,448 & 328,155 \\
POCP C $_{2} \mathrm{H}_{4-\mathrm{eq}} / \mathrm{kg}$ & 340,645 & 83,335 & 82,750 \\
\hline \hline
\end{tabular}

It was estimated that $81 \%$ \& $78 \%$ reduction in GWP resulted from implementing LTP in scenario II and VCC in scenario III to treat plastics and organics. The following figure (Fig. 7) shows the reduction GWP by using both technologies in addition to the load from Transportation and Landfilling where it is calculated that LTP unit has an advantage of $62 \%$ over VCC unit.

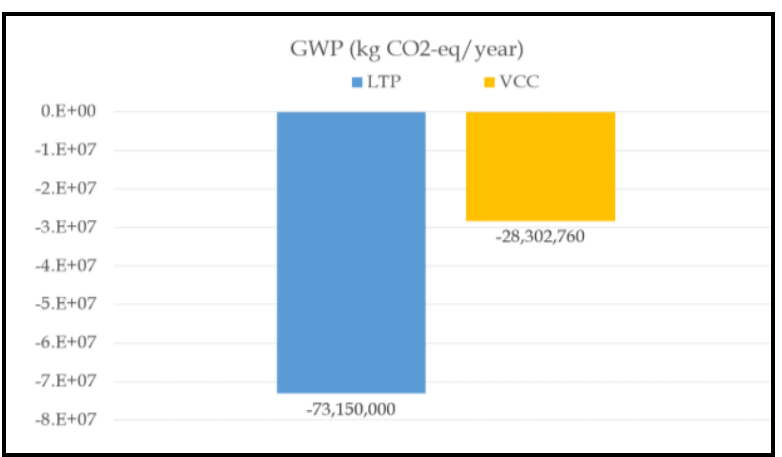

Fig. 7. LTP \& VCC comparisons in term of GWP.

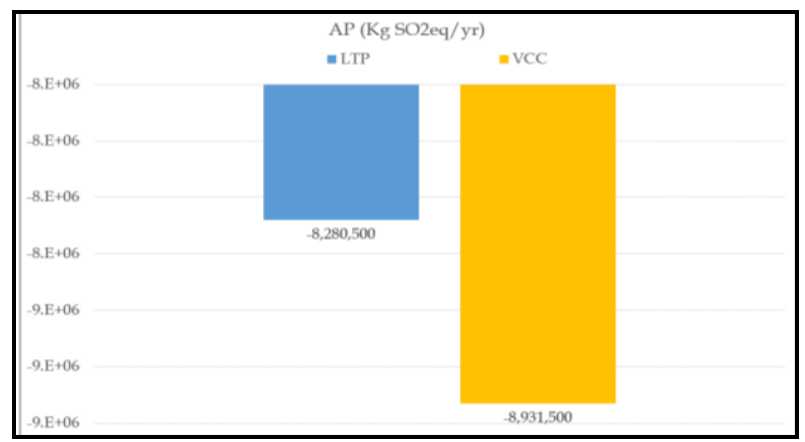

Fig. 8. LTP \& VCC comparisons in term of AP.
On the other hand, comparing the LTP \& VCC units in term of AP, EP \& POCP shows better results in VCC against LTP with minor difference in $\mathrm{AP}\left(7 \times 10^{5} \mathrm{SO} 2-\mathrm{eq} / \mathrm{kg}\right)$ and $\mathrm{EP}(1 \mathrm{X}$ $10^{8} \mathrm{PO}_{4}{ }^{3-}$ eq/kg) as shown in Fig. 8 and Fig. 9.

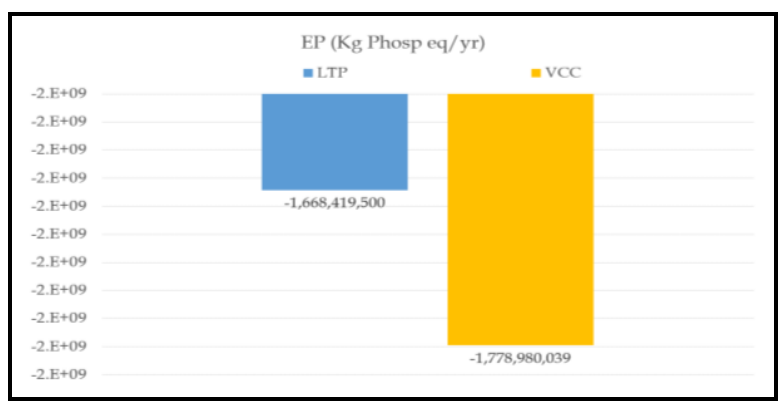

Fig. 9. LTP \& VCC comparisons in term of EP

Where around $45 \%$ reduction can be achieved of LTP vs. VCC for POCP (see Fig. 10).

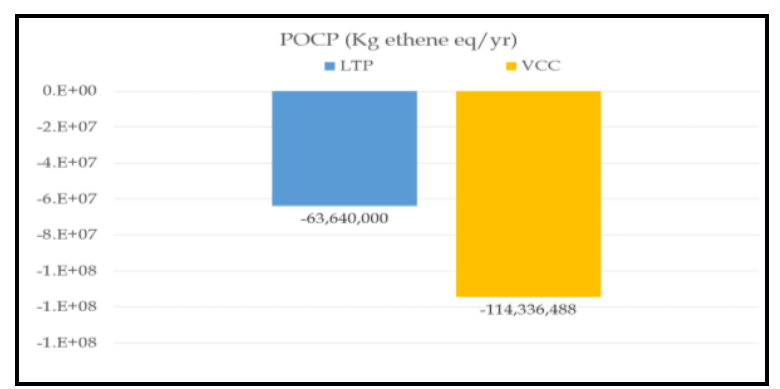

Fig. 10. LTP \& VCC comparisons in term of POCP.

\section{CONCLUSION}

Scenario 1 describes the current route in Kuwait, whilst scenarios 2 and 3 integrate IU \& TCT units. Reduction of $75-76 \%$ for the studied pollutants comes from Transportation and Landfilling before considering the IU and TCT units.

Incorporating IU is essential to reduce the impact of the studied pollutants in the state of Kuwait where it is noticed that there are a marginal preference VCC against LTP with minor difference in AP and EP and about $45 \%$ for POCP. In order to improve the Kuwaiti MSW the following points may considered:

- Cleaner technologies to produce energy.

- Start viewing solid waste as a source of energy.

- Recycling and producing energy from other fractions of waste (paper, cardboard, textiles, etc).

\section{REFERENCES}

[1] G. Finnveden and A. Moberg, "Environmental system analysis tools An overview," J. Cleaner Production, vol. 13, pp. 1165-1173, 2004.

[2] A. Tukker et al., "Chemical recycling of plastic waste: PVC and other resins," European Commission, DG III, Final Report, STB-99-55 Final, Delft, The Netherlands, 1999.

[3] F. Perugini, M. L. Mastellone, and U. Arena, "A life cycle assessment of mechanical and feedstock recycling options for management of plastic packaging wastes," Environ Progress, vol. 24, no. 2, pp. 137-154, 2005.

[4] H. H. Khoo, "Life cycle impact assessment of various waste conversion technologies," Waste Management, 2009.

[5] A.-J. Rawa and E. Aleisa, "A baseline study characterizing the municipal solid waste in the State of Kuwait," Waste Management, vol. 34, pp. 952-960, 2014.

[6] L. Yassin, "Appropriate scales and technologies for energy recovery by thermal waste processing," $\mathrm{PhD}$ Thesis, Department of Chemical Engineering, University College London, London, UK, 2007. 
[7] M. L. Mastellone, "Thermal treatments of plastic wastes by means of fluidized bed reactors," $\mathrm{PhD}$ thesis, Department of Chemical Engineering, Second University of Naples, Italy, 1999.

[8] The Public Authority for Civil Information. [Online]. Available: https://www.paci.gov.kw/Home.aspx

[9] P. Koushki, J. Alhumoud, and U. Al-Duaij, "Municipal solid waste in Kuwait: Trends and attitudes on collection, separation and willingness to pay," Kuwait Journal of Science and Engineering, vol. 31, no. 2, pp. 173-188, 2004.

[10] F. Perugini, M. L. Mastellone, and U. Arena, "A life cycle assessment of mechanical and feedstock recycling options for management of plastic packaging wastes," Environ Progress, vol. 24, no. 2, pp. 137-154, 2005.

[11] Shell, "Step in the right direction," Shell Magazine, 2010.

[12] AkzoNobel, Environmental production declaration: Ethylene amines, Report, 2005.

[13] Gabi 5 2013, Gabi software database (DB) version 5.43

[14] I. Staffell, A. Ingram, and K. Kendall, "Energy and carbon payback times for solid oxide fuel cell based domestic CHP," Int. Journal of Hydrogen Energy, vol. 37, no. 3, pp. 2509-2523, 2012.
[15] M. Fulton, N. Mellquist, S. Kitasei, and J. Bluestein, "Comparing life-cycle greenhouse gas emissions from natural gas and coal," World Watch Institute, August $25^{\text {th }} 2011$

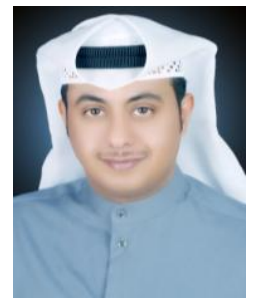

Ayed Al-Fadhli graduated from Kuwait University, College of Engineering \& Petroleum, holding a BSc (2005) and an MSc (2007) degrees in chemical engineering and and MSc (2012) degree in environmental science, where he started his career in 2004 as a projects \& special studies analyst as planning marketing at KPC International Marketing.

Eng. Al-Fadhli a volunteer researcher specializes in environmental aspects, which is the air pollution and life cycle assessment (LCA) is a particular research interest of his. He has authored/co-authored a number of refereed journal and conference papers. 